\title{
Article \\ Research on Carbon Reduction of Residential Buildings in Severe Cold Regions Based on Renovation of Envelopes
}

\author{
Han Yang ${ }^{1, *(\mathbb{C}, \text { Koki Kikuta }}{ }^{2}$ and Motoya Hayashi ${ }^{2}$ \\ 1 Graduate School of Engineering, Hokkaido University, Sapporo 060-8628, Japan \\ 2 Faculty of Engineering, Hokkaido University, Sapporo 060-8628, Japan; k-kikuta@eng.hokudai.ac.jp (K.K.); \\ motoya.hayashi@eng.hokudai.ac.jp (M.H.) \\ * Correspondence: han.yang.t8@elms.hokudai.ac.jp
}

Citation: Yang, H.; Kikuta, K.; Hayashi, M. Research on Carbon Reduction of Residential Buildings in Severe Cold Regions Based on Renovation of Envelopes. Energies 2022, 15, 1873. https://doi.org/ $10.3390 /$ en15051873

Academic Editors: Xi Chen,

Patrick Phelan and Azra Korjenic

Received: 19 January 2022

Accepted: 2 March 2022

Published: 3 March 2022

Publisher's Note: MDPI stays neutral with regard to jurisdictional claims in published maps and institutional affiliations.

Copyright: (c) 2022 by the authors. Licensee MDPI, Basel, Switzerland. This article is an open access article distributed under the terms and conditions of the Creative Commons Attribution (CC BY) license (https:/ / creativecommons.org/licenses/by/ $4.0 /)$.

\begin{abstract}
The demand for heating in cold regions drives up carbon emissions every year. In order to achieve China's carbon neutrality target by $2060, \mathrm{CO}_{2}$ emissions in the cold regions must be reduced. In this paper, using Design Builder software, a simulation model of residential buildings in severe cold regions was created, and the most appropriate parameter design scheme for carbon emission reduction of residential buildings in severe cold regions was derived by simulating the experimental data of the original parameter design scheme and the changed parameter design scheme, as well as the calculation of carbon dioxide emission reduction rate. In order to make the comparison of the results easier, no change was made in the selection of the changed scheme for the external insulation material, foamed polystyrene panels. The results show that the most suitable parameter scheme for houses in severe cold regions is $85 \mathrm{~mm}$ thick foamed polystyrene panels for exterior walls, $200 \mathrm{~mm}$ thick foamed polystyrene panels for roofs, and exterior windows should use semi-tempered plastic steel frame and triple glass $6 \mathrm{~mm}$ glass + vacuum $+6 \mathrm{~mm}$ low-e glass $+12 \mathrm{~mm}$ air $+6 \mathrm{~mm}$ glass composed of windows. This technique saves $30.32 \%$ of energy as compared to the original parameter design approach. The efficiency of energy conservation is $33.03 \%$. The emission reduction effect is significant. The best parametric design plan has a static payback period of 5 years. The best parametric design plan has a discounted payback period of 7 and a net present value of USD 65,413.39. This scheme can provide a great economic return while also increasing the performance of the building.
\end{abstract}

Keywords: severe cold area; carbon dioxide emission reduction rate; original parameters; changed parameters; simulation

\section{Introduction}

According to the Worldwide Global Carbon Project, China's carbon dioxide emissions in 2018 totaled 10.1 billion tons, ranking first in the world and accounting for $27.6 \%$ of global carbon dioxide emissions [1]. Greenhouse gas emissions have become a more global focus of concern since the Paris Agreement. According to the "China Building Energy Research Report (2020)", Chinese carbon dioxide emissions climbed by 6.6 percent every year from 2005 to 2018 , rising from 2.234 billion tons in 2005 to 4.932 billion tons in 2018. Figure 1 illustrates this. In 2018, China's overall carbon emissions from the construction process were 4.93 billion $\mathrm{tCO}_{2}$, accounting for 51.3 percent of the country's total emissions. The peak year for building carbon emissions is expected to be 2040, with a peak of 2.701 billion tons of $\mathrm{CO}_{2}$ [2]. Controlling the increase in building carbon emissions is critical for addressing the greenhouse effect issue.

China lowered its carbon emission intensity by $18.8 \%$ in 2020 compared to 2015, exceeding the $18 \%$ binding target outlined in the 13th Five-Year Plan [3]. China made a solemn vow to the world in September 2020, saying it will work to attain carbon peaks by 2030 and carbon peaking by 2060. The gradual fall of carbon emissions after peaking has also become an essential content in the "14th Five-Year Plan" and the 2035 long-term target framework [4]. 


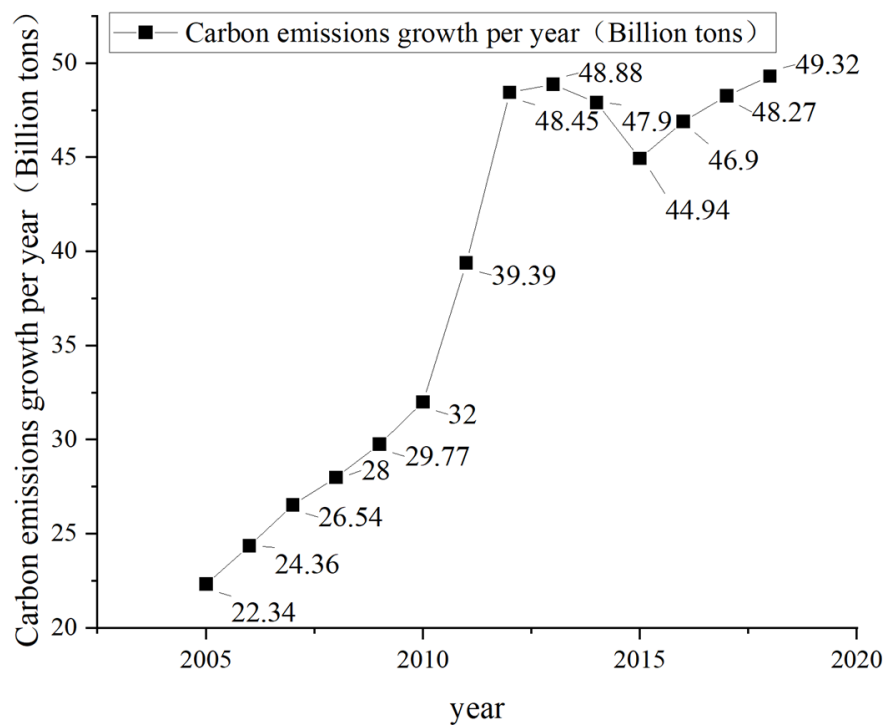

Figure 1. Growth of carbon emissions in China from 2005 to 2018.

In 2018, China's building operation carbon emissions totaled around 2.1 billion tons, accounting for almost $20 \%$ of the country's total emissions. Heating energy use in northern cities and towns is 212 million tons of standard coal, with 550 million tons of carbon emissions. As a result, research on reducing residential building carbon emissions in extremely cold places is required to lessen the burden of residential building heating carbon emissions on the climate and environment.

The design stage of a building is very important to effectively reduce the energy consumption of the building [5-7]. In order to reduce energy consumption in buildings, Carletti et al. [8] used the window as a changeable parameter to simulate the building's energy consumption using the EnergyPlus dynamic simulation system in order to lower the building's energy usage. Alam et al. [9] used the EnergyPlus dynamic modeling system to simulate building energy consumption by adding PCM to the shell structure. According to the findings, adding PCM to buildings can save $17-23 \%$ of energy. Ahmad Arabkoohsar [10] conducted simulation experiments in the design stage to reduce energy usage while researching and exploring a new form of solar energy hybrid intelligent building energy system. Haie Huo et al. [11] conducted simulation research on a single building's energy use. The result is that the heat transfer between the roof and the external walls is the primary cause of the building model's total annual load. A. Feehan et al. [12] used the BES-LCA framework to model the impact of exterior window and glazing design changes in loads of a Berlin office building and then chose the most energy-efficient design solutions. Frida Bazzocchi et al. [13] used different perspectives in the design phase to select the best energy-efficient building envelope design in Italy from energy, environmental and economic points of view. Phillipe R. Sampaio et al. [14] used a grey-box model of the building and meteorological data to perform a black-box multi-objective optimization calibration in order to reduce building energy usage during the design stage.

In order to improve the efficiency of construction, Chuan-Hsuan Lin et al. [15] integrated the building geometry, wind environment, and thermal comfort assessment during the design stage and chose more solutions to improve energy efficiency, comfort, and health of occupants. MehdiTavakolan et al. [16] used EnergyPlus for dynamic simulation to perform comprehensive simulation analysis of possible scenarios to improve the energy efficiency of the building. Daranee Jareemit [17] used the eQuest model to examine residential cooling energy consumption. Increases in the solar heat gain coefficient of the windows, the U-value of the walls, and the length of the eaves can reduce energy consumption and increase the building's energy efficiency, according to the findings. In conclusion, parameter evaluation and optimization during the design phase improve building energy efficiency 
and reduce energy consumption, indicating that parameter evaluation and optimization during the design phase also reduce building $\mathrm{CO}_{2}$ emissions.

Although many studies were conducted by existing scholars on the energy consumption of residential buildings in the severe cold regions of China [18-21], few focused on reducing $\mathrm{CO}_{2}$ emissions in the design phase of residential buildings in the severe cold regions of China.

Residential buildings in Changchun, Jilin Province, China, were chosen for simulation studies to simulate the effects of different parameters on $\mathrm{CO}_{2}$ emissions of residential buildings in the design phase, while a quantitative model for residential economic evaluation and a sensitivity analysis model was established in the design phase to evaluate the rationality of residential design solutions. The residential emission reduction design scheme that best meets the parameters related to residential building carbon emission reduction in extremely cold regions is provided. Section 2 introduces the simulation software, computational model, and research flow chart used in this study. Section 3 specifies the project overview, describes the parameter values and establishes the project's simulation model. Section 4 analyzes and discusses the simulation results. Section 5 draws to a conclusion.

\section{Research Methods}

\subsection{Simulation Software}

Design Builder is a comprehensive user graphical interface simulation software developed for building energy consumption dynamic simulation programs (energy plus). Energy plus, a powerful building energy simulation engine, is jointly developed by the U.S. Department of Energy (DOE) and Lawrence Berkeley National Laboratory (LBNB) in the United States. It can be used to simulate and analyze building heating, cooling, ventilation, and other energy consumption in a comprehensive manner [22]. The Design Builder software combines quick building modeling with ease of use. Even non-professional users can model complicated buildings in a short amount of time. Correct environmental performance data, as well as high-quality photos and animations, can be provided at each point of the operation.

\subsection{Computational Model}

\subsubsection{Computational Model for Reducing Carbon Dioxide Emission Rate}

Energy-saving efficiency is an index that evaluates the impact of parameters on building energy performance [23]. Since this article needs to evaluate the impact of parameters on carbon oxide emissions from buildings in two years, this article chooses the rate of carbon dioxide emission reduction as the evaluation index. The computational model of the carbon dioxide emission rate is constructed as Equation (1).

$$
\mathrm{RCDE}=\frac{\mathrm{CDEPOP}-\mathrm{DEPMP}}{\mathrm{CDEPMP}} \times 100 \%
$$

where RCDE is the reduced carbon dioxide efficiency, CDEPMP represents the building carbon dioxide emissions per year of a modified parameter plan in $\mathrm{kg}$, and CDEPOP represents the building carbon dioxide emissions per year of the original parameter plan in $\mathrm{kg}$.

\subsubsection{Economic Indicators}

Because economic indicators must assess the economic feasibility and intuitively determine the program's entire benefits, as a result, the static investment payback period and net present value are used as economic indicators in this article.

\section{(1) Net Present Value.}

The net present value refers to the difference between the net cash flow generated by the investment plan and the present value of the original investment after discounting the cost of funds as the discount rate [24]. For this article, the net present value is the 
difference between the total annual cost savings of residential buildings after the design and renovation and the incremental cost of residential buildings after the design and renovation during the building service life. The computational model of net present value is constructed as Equation (2).

$$
N P V=\sum_{t=1}^{n}(C I-C O)(1+i)^{-t}
$$

where NPV is net present value in USD, CI represents annual savings after design transformation in USD, CO represents the difference between initial investment cost before design transformation and after design transformation in USD, $t$ represents calculation year in years, $i$ represents social discount rate.

There are two main types of calculated costs for the indicator: the value of annual cost savings after the design retrofit and the difference between the initial investment cost before the design retrofit and after the design retrofit.

A. Annual cost savings after design and transformation.

The annual savings after the design and transformation should include energy savings and carbon trading costs. The computational model is Equation (3). After the design and renovation of exterior walls, exterior windows, and roofs, the annual energy consumption of the building is reduced. Therefore, the number of raw materials for energy supply (calculated by coal) is reduced, thereby saving costs. After the design and renovation, the carbon emissions generated by residential buildings are reduced, and transactions can be carried out according to the price of the Jilin Province carbon trading market to save costs. The computational model is constructed as Equations (4) and (5).

$$
\begin{gathered}
C I=C_{1}+C_{2} \\
C_{1}=\frac{E \times 3600 \times 24 \times 120}{\theta \times 10^{6} \times \eta} \times F \\
C_{2}=T \times F_{C}
\end{gathered}
$$

where $C_{1}$ represents the coal saving cost of transformation in USD, $C_{2}$ represents carbon trading fees after transformation in USD. $E$ represents total energy consumption saved by the transformation plan in MWh. F represents the market price of standard coal in USD. $\theta$ represents the calorific value of standard coal. $\eta$ represents combustion efficiency of heating and combustion in $\mathrm{kJ} / \mathrm{kg}$. $T$ represents total carbon emissions reduced by the renovation plan in $\mathrm{kg} . F_{c}$ represents Carbon trading price in USD.

B. The initial investment cost difference before design transformation and after design transformation.

The difference between the initial investment cost before the design retrofit and after the design retrofit includes the cost of insulation materials, labor, and machinery [25]. This article mainly calculates the cost based on the 2019 version of the Jilin Province construction project pricing budget quota.

\section{(2) Static Payback Period.}

The static payback period is the time required for the project's net income to recover its entire investment [26]. For this article, the static payback period is the time during which the annual cost savings after the residential building renovation are equal to the incremental cost of the residential building renovation.

(3) Discounted Payback Period.

The discounted payback period is the total time required to offset the present value of the original investment with the present value of the net cash flow of the investment 
project, taking into account the time value of money [21]. The computational model of net present value is constructed as Equation (6).

$$
P_{t}=\left(N_{1}-1\right)+\frac{C_{3}}{C_{4}}
$$

Pt represents the discounted payback period in years. $N_{1}$ indicates the year in which the cumulative net cash flow is positive in years, and $C_{3}$ represents the absolute value of the present value of the cumulative net cash flow in the previous year in USD. $C_{4}$ indicates the present value of the net cash flow in the year in which the positive value occurs in USD.

\subsection{Study Flow Chart}

Simulate the residential building's energy consumption and carbon emissions using Design Builder software. Figure 2 depicts the procedure. The step-by-step description of the flowchart is as follows:

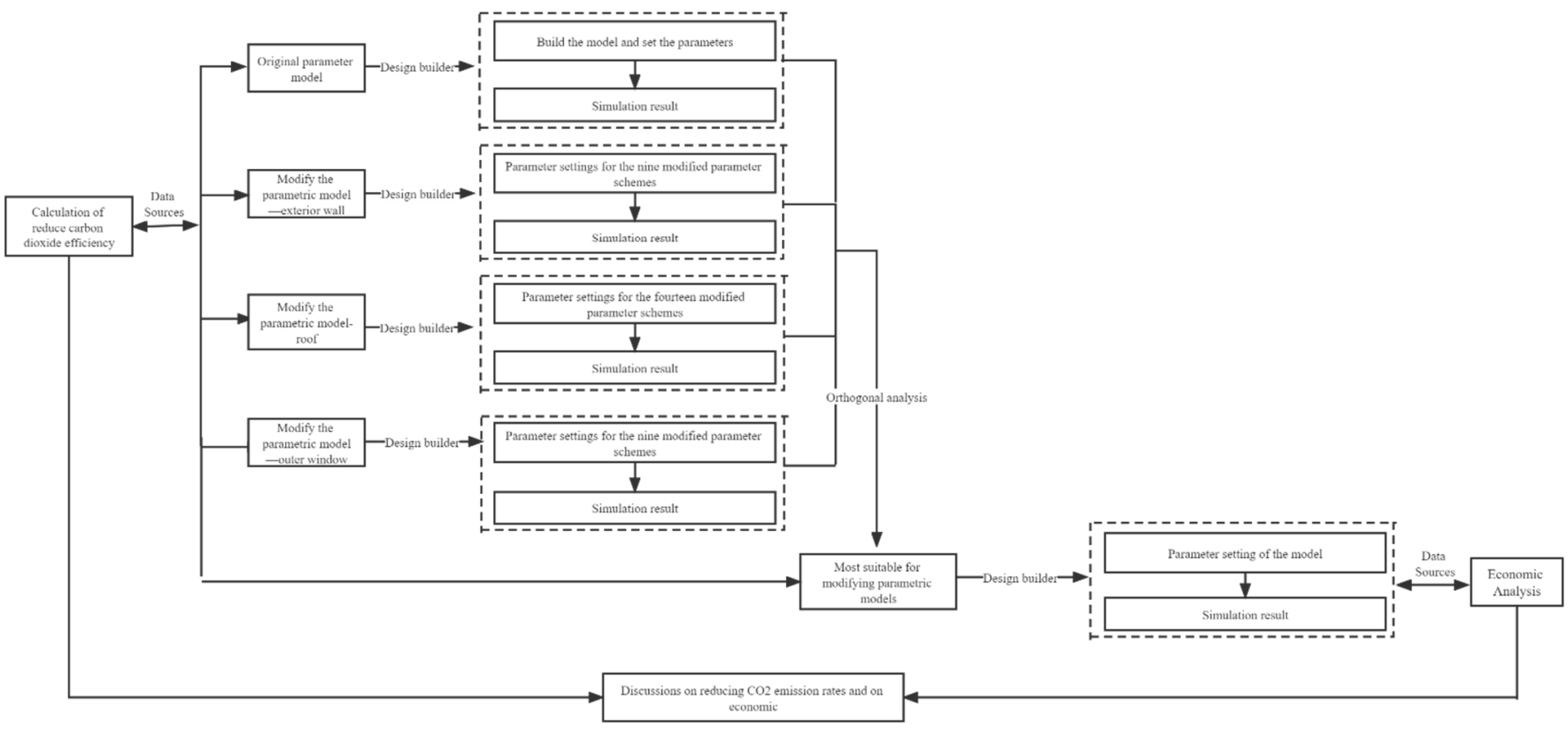

Figure 2. Study flow chart.

Step 1: Make a model for calculating. The calculating model's data source is mostly Design Builder software simulation data;

Step 2: Create the initial parameter model. Set the parameters and run the simulation with Design Builder software to see how much energy is used and how much carbon dioxide is emitted;

Step 3: Establish and modify the parameter model. For parameter configuration, modify parameter schemes for 9 outside walls, 14 roof modification parameters, and 9 exterior window modification parameters, then use Design Builder software to simulate and simulate carbon dioxide emissions;

Step 4: Calculate the modified parameter plan's carbon dioxide emission reduction rate, assess the impact of the parameters on residential building carbon dioxide emissions, and choose the right parameter plan for residential buildings in extremely cold climates. Additionally, utilize Design Builder software to run simulations to establish how much energy is used and how much carbon dioxide is emitted;

Step 5: The most suitable parameter solutions for residential buildings in severe cold regions were analyzed by combining different perspectives of economic analysis and carbon emission analysis for 17 groups of tested solutions, and the most suitable parameter 
solutions for residential buildings in severe cold regions were analyzed by combining different perspectives of economic analysis and carbon emission analysis.

\section{Case Selection and Construction Parameters}

\subsection{Project Overview and Original Design Parameter Scheme}

Changchun City is in the Song Liao Plain in the hinterland of the Northeast Plain of China, which belongs to the middle $\mathrm{C}$ zone in the severe cold area. The lowest average temperature in January is $-19.9^{\circ} \mathrm{C}$, and the highest average temperature in July is $27.6^{\circ} \mathrm{C}$. The sunshine time is $2688 \mathrm{~h}$, the annual precipitation is $600-700 \mathrm{~mm}$, and the summer precipitation accounts for more than $60 \%$ of the annual precipitation [27]. The indoor temperature of the research object in winter heating should be $18{ }^{\circ} \mathrm{C}$, and the calculated air change frequency in winter heating should be 0.5 times/h. For places with lighting in the model, the lighting power is set to $5 \mathrm{~W} / \mathrm{m}^{2}$. The simulation model established in Design Builder is shown in Figure 3.
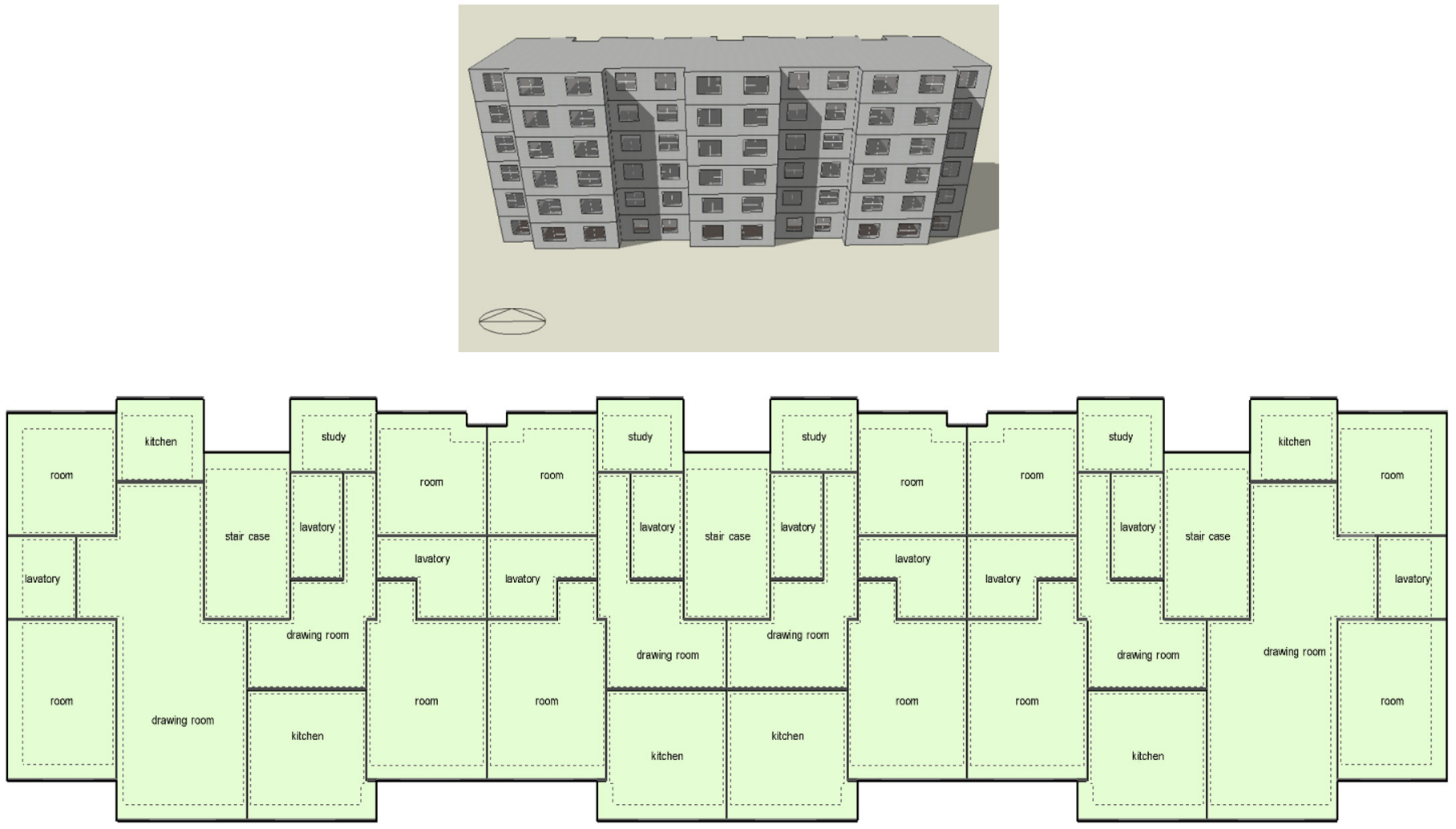

Figure 3. Simulation model of a residential building.

The project is a residential building in Changchun City, with a total construction area of 3139.56 square meters and a floor area of 544.32 square meters. The building has 6 floors above ground and no underground buildings. The total building height is $16.8 \mathrm{~m}$, and the floor height is $2.8 \mathrm{~m}$. The shape factor is 0.32 . The building structure is a reinforced concrete shear wall structure with a building life of 50 years. The construction period was relatively early in 2009. Jilin Province has not yet implemented the "Design Standards for Energy Efficiency of Residential Buildings in Severe Cold and Cold Areas "JGJ26-2018 [28]". The original design parameters are shown in Table 1. 
Table 1. Original design parameters (OP).

\begin{tabular}{ccc}
\hline Design Parameters & Data & Heat Transfer Coefficient \\
\hline Exterior wall & $\begin{array}{c}25 \mathrm{~mm} \text { cement mortar }+370 \mathrm{~mm} \text { hollow clay brick }+20 \mathrm{~mm} \text { EPS } \\
\text { polystyrene foam board }+8 \mathrm{~mm} \text { cement mortar }\end{array}$ & 1.16 \\
Roof & $\begin{array}{c}40 \mathrm{~mm} \text { fine stone reinforced concrete }+30 \mathrm{~mm} \text { EPS polystyrene } \\
\text { foam board }+1.2 \mathrm{~mm} \text { waterproof coiled material }+20 \mathrm{~mm} \text { cement } \\
\text { mortar leveling layer }+30 \mathrm{~mm} \text { lightweight aggregate concrete } \\
\text { slope finding }+120 \mathrm{~mm} \text { reinforced concrete roof slab }\end{array}$ & 1.06 \\
& Plastic frame and double glass window $(5+6+5 \mathrm{~mm})$ & 3.13 \\
Exterior window & North: 0.20 \\
Floor height & East: 0.25 \\
Window-to-wall ratio & South: 0.30 \\
Weating method & Central heating-city heating \\
\hline
\end{tabular}

\subsection{Modification Parameters}

The thermal performance of the envelope structure is a key factor affecting the carbon emissions and energy consumption of residential buildings in severe cold areas. The heat loss through the envelope structure accounts for $70-80 \%$ of the heat loss of the building [29]. According to calculations, the heat transfer coefficients of exterior walls, exterior windows, and roofs of residential buildings in severe cold areas of China are 3-5 times that of developed countries at the same latitude [30]. As a solution, this article uses Design Builder software to simulate energy consumption and carbon emissions using exterior windows, exterior walls, and roofs as transformation parameters.

According to the "Design Standards for Energy Conservation of Civil Buildings in Jilin Province (Energy Conservation 65\%)" [31], the thickness of the outer wall of the building shall not exceed $490 \mathrm{~mm}$. Therefore, the design plan for the transformation parameters is shown in Tables $2-4$.

Table 2. Modification parameter design plan (MP)—External wall insulation thickness.

\begin{tabular}{cc}
\hline External Wall Insulation Thickness $(\mathbf{m m})$ & Thermal Transmittance $\left(\mathbf{W} /\left(\mathbf{m}^{\mathbf{2}} \cdot \mathbf{k}\right)\right)$ \\
\hline MP1 $=45$ & 0.515 \\
MP2 $=50$ & 0.485 \\
MP3 $=55$ & 0.458 \\
MP4 $=60$ & 0.433 \\
MP5 $=65$ & 0.412 \\
MP6 $=70$ & 0.392 \\
MP7 $=75$ & 0.374 \\
MP8 $=80$ & 0.358 \\
MP9 $=85$ & 0.343 \\
\hline
\end{tabular}

Table 3. Modification parameter design plan (MP)—Roof insulation thickness.

\begin{tabular}{|c|c|c|c|}
\hline $\begin{array}{c}\text { Roof Insulation } \\
\text { Thickness } \\
\text { (mm) }\end{array}$ & $\begin{array}{c}\text { Thermal } \\
\text { Transmittance } \\
\left(\mathrm{W} /\left(\mathrm{m}^{2} \cdot \mathrm{k}\right)\right)\end{array}$ & $\begin{array}{l}\text { Roof Insulation } \\
\text { Thickness } \\
\text { (mm) }\end{array}$ & $\begin{array}{c}\text { Thermal } \\
\text { Transmittance } \\
\left(\mathrm{W} /\left(\mathrm{m}^{2} \cdot \mathbf{k}\right)\right)\end{array}$ \\
\hline $\mathrm{MP} 10=40$ & 0.752 & $\mathrm{MP} 17=180$ & 0.211 \\
\hline $\mathrm{MP} 11=60$ & 0.550 & $\mathrm{MP} 18=200$ & 0.191 \\
\hline $\mathrm{MP} 12=80$ & 0.434 & MP19 $=250$ & 0.155 \\
\hline $\mathrm{MP13}=100$ & 0.358 & $\mathrm{MP20}=300$ & 0.130 \\
\hline $\mathrm{MP} 14=120$ & 0.284 & $\mathrm{MP} 21=350$ & 0.112 \\
\hline $\mathrm{MP} 15=140$ & 0.265 & $\mathrm{MP} 22=400$ & 0.099 \\
\hline $\mathrm{MP} 16=160$ & 0.235 & $\mathrm{MP} 23=450$ & 0.088 \\
\hline
\end{tabular}


Table 4. Modification parameter design plan (MP)—Exterior window.

\begin{tabular}{ccc}
\hline Exterior Window & $\begin{array}{c}\text { Thermal Transmittance } \\
\left(\mathbf{W} /\left(\mathbf{m}^{2} \cdot \mathbf{k}\right)\right)\end{array}$ & $\begin{array}{c}\text { Solar Heat Gain } \\
\text { Coefficient }(\mathrm{SHGC})\end{array}$ \\
\hline MP24 = Plastic steel frame and triple glass window 5 + 9 + 4Low-e + 12 (Ar) + 5 & 1.47 & 0.503 \\
\hline MP25 = Plastic steel frame and triple glass window 3 + 11 + 3Low-e + 11 (Ar) + 3 & 1.40 & 0.518 \\
\hline MP26 = Plastic steel frame and triple glass window 4 + 10 + 4Low-e + 10 (Ar) + 4 & 1.34 & 1.13 \\
\hline MP27 = Plastic steel frame and double glass window 6 + V + 6Low-e & 0.95 & 0.511 \\
\hline MP28 = Plastic steel frame and triple glass window 6 + V + 6Low-e + P + 6 & 0.81 & 0.562 \\
\hline MP29 = Plastic steel frame and triple glass window 6 + V + 6Low-e + 12A + 6 & 0.77 & 0.541 \\
\hline MP30 = Plastic steel frame and quadruple glass window 6 + 12A + 6 + V + 6Low-e + P + 6 & 0.69 \\
\hline MP31 = Semi-tempered plastic steel frame and double glass window 6 + V + 6Low-e & 0.61 \\
\hline MP32 = Semi-tempered plastic steel frame and triple glass window 6 + V + 6Low-e + 12A + 6 & 0.523 \\
\hline OP & 3.13 \\
\hline
\end{tabular}

\section{Results and Discussion}

The original design plan model was modified 33 times in accordance with the project's current circumstances. In order to determine the carbon dioxide reduction rate of the design retrofit programs based on the simulation findings, apply the computational model of carbon dioxide reduction rate Equation (1).

\subsection{Exterior Wall}

Based on the original design of annual carbon dioxide emissions, the relationship between MP1 and MP9 and the emission reduction rate is shown in Figure 4.

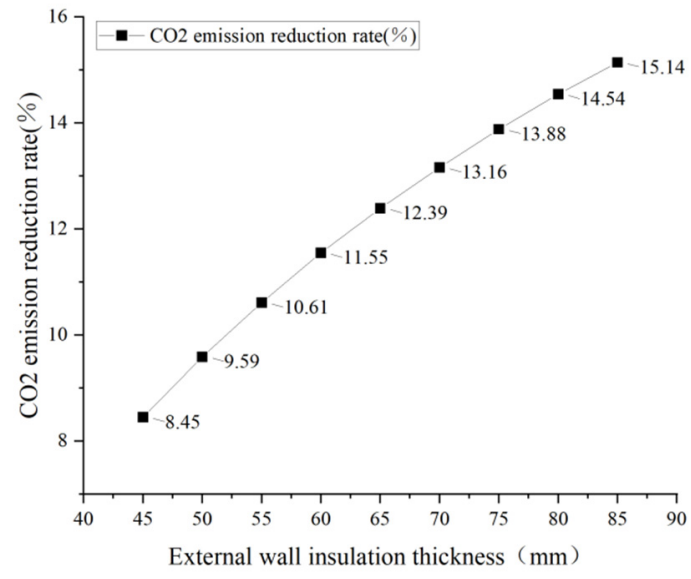

Figure 4. $\mathrm{CO}_{2}$ emission reduction rate of different external wall insulation thicknesses.

As can be seen, increasing the thickness of the insulation material is positively correlated with reducing the carbon dioxide emissions of the building, and the carbon dioxide emissions are gradually decreasing as the thickness of the insulation material increases; the rate of reducing carbon dioxide emissions is gradually increasing. When the thickness of the EPS polystyrene foam board is $85 \mathrm{~mm}$, the maximum can reach $15.14 \%$. This shows that increasing the thickness of the outer wall insulation of residential buildings in severe cold areas is effective in increasing the reduction in carbon dioxide emissions.

\subsection{Roof}

Based on the original designed annual carbon dioxide emissions, the relationship between MP10 and MP23 and the emission reduction rate is shown in Figure 5. 


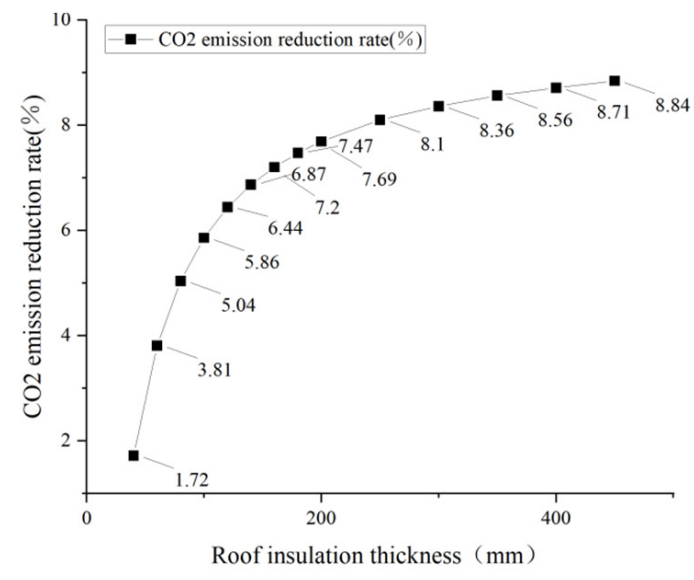

Figure 5. $\mathrm{CO}_{2}$ emission reduction rate of different roof insulation thicknesses.

Increasing the thickness of the insulation material is positively related to reducing the carbon dioxide emissions of the building when compared to the original design of $30 \mathrm{~mm}$ EPS polystyrene foam board, and as the thickness of the insulation material increases, the carbon dioxide emissions gradually decrease. The rate of carbon dioxide emissions is steadily growing. The highest can reach 8.84 percent when the EPS polystyrene foam board thickness is $450 \mathrm{~mm}$. It is worth mentioning, however, that as the thickness of the roof insulation board increases, the impact on the rate of emission reduction decreases. As a result, increasing the thickness of the roof insulation layer of residential structures in severe cold places is efficient in improving the rate of carbon dioxide emission reduction, but the benefit diminishes as the insulation layer thickness increases.

\subsection{External Windows}

Based on the original designed annual carbon dioxide emissions, the relationship between MP24 and MP32 and the emission reduction rate is shown in Figure 6.

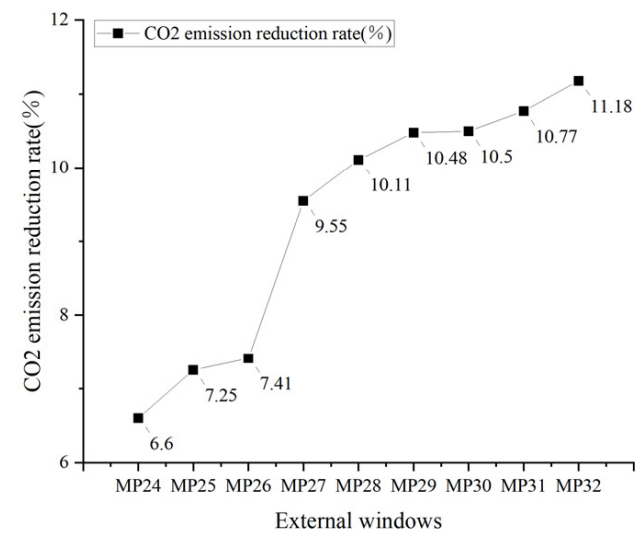

Figure 6. $\mathrm{CO}_{2}$ emission reduction rate of different window types.

As can be observed, the MP32 program's carbon dioxide emission reduction rate is up to $11.18 \%$. This shows that installing high-performance exterior windows in residential buildings in severe cold areas can help reduce carbon dioxide emissions. The smaller the SHGC value, the better the thermal insulation performance, so in severe cold areas, a window with a large SHGC value should be chosen [32]. According to the "Glass Curtain Wall Thermal Performance GB/T18091-2015", SHGC should not be greater than 0.75 in severe cold areas [33]. Therefore, when the $\mathrm{K}$ value is similar or the same, windows with a large SHGC value should be selected as much as possible to reduce heat loss and thereby reduce carbon dioxide emissions. 


\subsection{Optimal Parameter Modification Plan}

It is necessary to consider the factors that can affect residential carbon emissions in order to obtain the best parameter transformation plan. This paper selects three factors that affect the annual carbon emission of residential buildings: exterior wall A, roof B, and exterior window C. Each influencing factor takes four levels. The orthogonal test method is used to test and obtain the optimal parameter modification plan. From the above simulation results, it can be concluded that the thickness of the outer wall insulation layer, the heat transfer coefficient of the outer window, and the thickness of the roof insulation layer are positively correlated with the annual carbon emissions. The influencing factors and levels of the orthogonal test are shown in Table 5.

Table 5. Table of orthogonal levels and factors.

\begin{tabular}{|c|c|c|c|}
\hline Level & Exterior Wall A & Roof B & Outer Window C \\
\hline 1 & $\begin{array}{l}70 \mathrm{~mm} \text { EPS } \\
\text { polystyrene foam } \\
\text { board (A1) }\end{array}$ & $\begin{array}{l}140 \mathrm{~mm} \text { EPS } \\
\text { polystyrene foam } \\
\text { board (B1) }\end{array}$ & $\begin{array}{l}\text { Plastic steel frame and triple } \\
\text { glass window } 6+\mathrm{V}+6 \text { Low-e }+ \\
12 \mathrm{~A}+6(\mathrm{C} 1)\end{array}$ \\
\hline 2 & $\begin{array}{l}75 \mathrm{~mm} \text { EPS } \\
\text { polystyrene foam } \\
\text { board (A2) }\end{array}$ & $\begin{array}{l}160 \mathrm{~mm} \text { EPS } \\
\text { polystyrene foam } \\
\text { board (B2) }\end{array}$ & $\begin{array}{c}\text { Plastic steel frame and } \\
\text { quadruple glass window } 6+12 \mathrm{~A} \\
+6+\mathrm{V}+6 \text { Low }-\mathrm{e}+\mathrm{P}+6(\mathrm{C} 2)\end{array}$ \\
\hline 3 & $\begin{array}{l}80 \mathrm{~mm} \text { EPS } \\
\text { polystyrene foam } \\
\text { board (A3) }\end{array}$ & $\begin{array}{l}180 \mathrm{~mm} \text { EPS } \\
\text { polystyrene foam } \\
\text { board (B3) }\end{array}$ & $\begin{array}{l}\text { Semi-tempered plastic steel } \\
\text { frame and double glass window } \\
\qquad 6+V+6 \text { Low-e (C3) }\end{array}$ \\
\hline 4 & $\begin{array}{l}85 \mathrm{~mm} \text { EPS } \\
\text { polystyrene foam } \\
\text { board (A4) }\end{array}$ & $\begin{array}{l}200 \mathrm{~mm} \text { EPS } \\
\text { polystyrene foam } \\
\text { board (B4) }\end{array}$ & $\begin{array}{c}\text { Semi-tempered plastic steel } \\
\text { frame and triple glass window } 6 \\
+V+6 \text { Low-e }+12 A+6(C 4)\end{array}$ \\
\hline
\end{tabular}

\subsubsection{Visual Analysis}

As this paper selects three influences and four levels, the $L_{16}\left(3^{4}\right)$ orthogonal table was chosen, as shown in Table 6.

In Table $6, K_{1}, K_{2}, K_{3}$, and $K_{4}$, respectively, represent the total annual carbon emissions of the building under the various factors and levels, and $\overline{K 1}, \overline{K 2}, \overline{K 3}$, and $\overline{K 4}$ represents the average annual carbon emissions of the building under the various factors and levels. $K_{5}, K_{6}, K_{7}$, and $K_{8}$, respectively, represent the total annual energy consumption of the building under each factor and each level, and $\overline{K 5}, \overline{K 6}, \overline{K 7}$, and $\overline{K 8}$ represents the average annual energy consumption of the building under each factor and each level. Since the number of levels may be different, the average annual carbon emissions and annual energy consumption are generally used to reflect the degree of influence of different levels of the same factor on the test results and to determine the best value for this factor level. The range value $R$ of the average value at each level of the same factor is used to reflect the influence of the level changes in each factor on the test results. The greater the $R$-value, the greater the impact of the factor level change on the test results, and vice versa.

From Figure $7 a, b$, it can be concluded that the main order of the influencing factors of the annual carbon emission of the project is the external wall (A), roof (B), and external window $(\mathrm{C})$ in order of influence. The annual energy consumption of the project is as follows: external wall (A), roof (B), and external window (C). The best solution to reduce carbon emissions is A4B4C4, $85 \mathrm{~mm}$ EPS polystyrene foam board (A4), $200 \mathrm{~mm}$ EPS polystyrene foam board (B4), semi-tempered plastic steel frame, and triple glass window 6 $+\mathrm{V}+6$ Low-e $+12 \mathrm{~A}+6(\mathrm{C} 4)$. However, the optimal parameter design scheme is not in the 16 test combinations and requires validation experiments. 
Table 6. Orthogonal test table.

\begin{tabular}{|c|c|c|c|c|c|c|}
\hline & $\begin{array}{c}\text { Test } \\
\text { Count }\end{array}$ & $\begin{array}{l}\text { Exterior } \\
\text { Wall A }\end{array}$ & $\begin{array}{c}\text { Roof } \\
\text { B }\end{array}$ & $\begin{array}{c}\text { Outer } \\
\text { Window C }\end{array}$ & $\begin{array}{c}\text { Carbon } \\
\text { Emissions } \\
\text { (kg) }\end{array}$ & $\begin{array}{c}\text { Energy } \\
\text { Consumption } \\
\text { (MWh) }\end{array}$ \\
\hline & 1 & A1 & B1 & $\mathrm{C} 1$ & $120.32 \times 10^{3}$ & 323.65 \\
\hline & 2 & A1 & B2 & $\mathrm{C} 2$ & $119.71 \times 10^{3}$ & 321.81 \\
\hline & 3 & A1 & B3 & C3 & $118.79 \times 10^{3}$ & 319.02 \\
\hline & 4 & A1 & B4 & C4 & $117.74 \times 10^{3}$ & 315.81 \\
\hline & 5 & $\mathrm{~A} 2$ & B1 & $\mathrm{C} 2$ & $119.08 \times 10^{3}$ & 319.95 \\
\hline & 6 & A2 & B2 & $\mathrm{C} 1$ & $118.56 \times 10^{3}$ & 318.34 \\
\hline & 7 & $\mathrm{~A} 2$ & B3 & $\mathrm{C} 4$ & $116.92 \times 10^{3}$ & 313.36 \\
\hline & 8 & $\mathrm{~A} 2$ & B4 & C3 & $117.22 \times 10^{3}$ & 314.30 \\
\hline & 9 & A3 & B1 & $\mathrm{C} 3$ & $117.52 \times 10^{3}$ & 315.25 \\
\hline & 10 & A3 & B2 & $\mathrm{C} 4$ & $116.84 \times 10^{3}$ & 313.17 \\
\hline & 11 & A3 & B3 & $\mathrm{C} 1$ & $117.02 \times 10^{3}$ & 313.65 \\
\hline & 12 & A3 & B4 & $\mathrm{C} 2$ & $116.60 \times 10^{3}$ & 312.40 \\
\hline & 13 & $\mathrm{~A} 4$ & B1 & C4 & $115.82 \times 10^{3}$ & 310.11 \\
\hline & 14 & $\mathrm{~A} 4$ & B2 & $\mathrm{C} 3$ & $115.93 \times 10^{3}$ & 310.46 \\
\hline & 15 & A4 & B3 & $\mathrm{C} 2$ & $115.95 \times 10^{3}$ & 310.47 \\
\hline & 16 & A 4 & $\mathrm{~B} 4$ & $\mathrm{C} 1$ & $115.62 \times 10^{3}$ & 309.44 \\
\hline \multirow[t]{18}{*}{ Result } & K1 & $476.56 \times 10^{3}$ & $472.74 \times 10^{3}$ & $471.52 \times 10^{3}$ & & \\
\hline & $\mathrm{K} 2$ & $471.78 \times 10^{3}$ & $471.04 \times 10^{3}$ & $471.34 \times 10^{3}$ & & \\
\hline & K3 & $467.98 \times 10^{3}$ & $468.68 \times 10^{3}$ & $469.46 \times 10^{3}$ & & \\
\hline & K4 & $463.32 \times 10^{3}$ & $467.18 \times 10^{3}$ & $467.32 \times 10^{3}$ & & \\
\hline & $\overline{K_{1}}$ & 119,140 & 118,185 & 117,880 & & \\
\hline & $\overline{K_{2}}$ & 117,945 & 117,760 & 117,835 & & \\
\hline & $\overline{K_{3}}$ & 115,995 & 117,170 & 117,365 & & \\
\hline & $\overline{K_{4}}$ & 115,830 & 116,795 & 116,830 & & \\
\hline & $\mathrm{R} 1$ & 3310 & 1390 & 1050 & & \\
\hline & K5 & 1280.29 & 1268.96 & 1265.08 & & \\
\hline & K6 & 1265.95 & 1263.78 & 1264.63 & & \\
\hline & K7 & 1254.47 & 1256.5 & 1259.03 & & \\
\hline & K8 & 1240.48 & 1251.95 & 1252.45 & & \\
\hline & $\overline{K_{5}}$ & 320.0725 & 317.24 & 316.27 & & \\
\hline & $\overline{K_{6}}$ & 316.4675 & 315.945 & 316.1575 & & \\
\hline & $\overline{K_{7}}$ & 314.4 & 314.125 & 314.7575 & & \\
\hline & $\overline{K_{8}}$ & 311.34 & 312.9875 & 313.1125 & & \\
\hline & $\mathrm{R} 2$ & 8.7325 & 4.2525 & 3.1575 & & \\
\hline
\end{tabular}

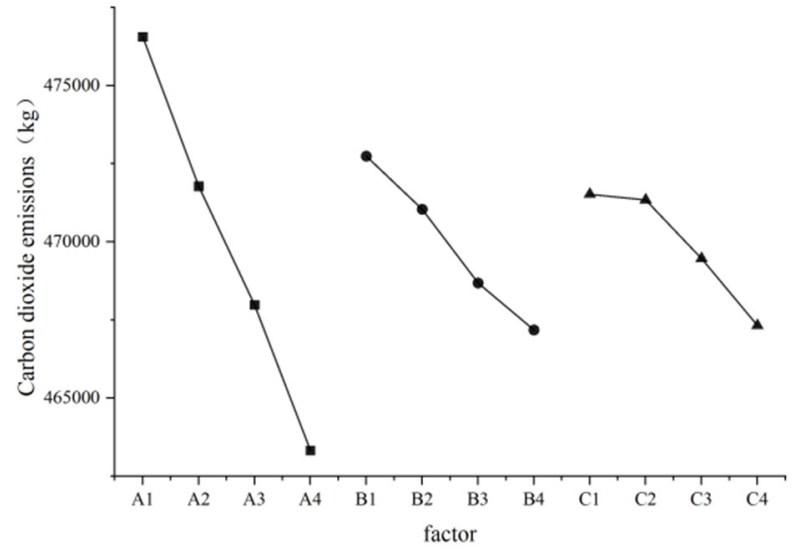

(a)

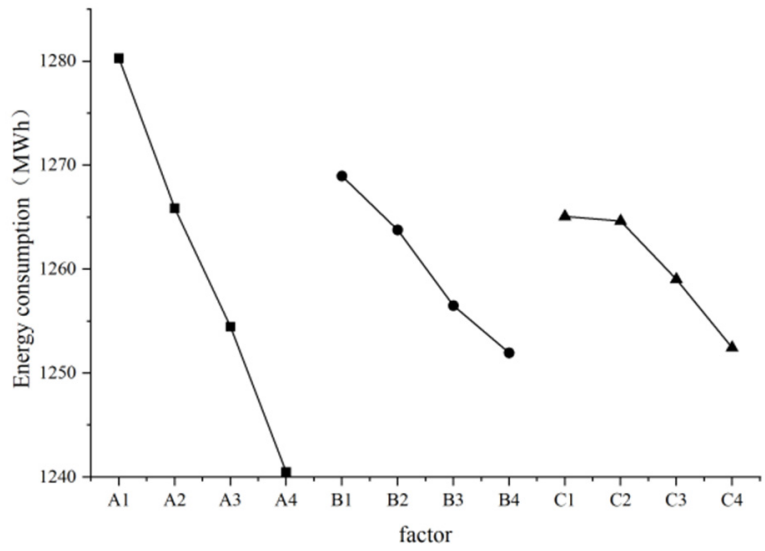

(b)

Figure 7. (a) Annual carbon emission effect graph; (b) annual energy consumption effect curve.

\subsubsection{Verification Experiment}

Perform a verification experiment on the optimal combination, and combine the optimal test combination A4B4C4, namely $85 \mathrm{~mm}$ EPS polystyrene foam board (A4), $200 \mathrm{~mm}$ EPS polystyrene foam board (B4), semi-tempered plastic steel frame, and triple glass window $6+\mathrm{V}+6 \mathrm{Low}-\mathrm{e}+12 \mathrm{~A}+6(\mathrm{C} 4)$. With the best combination in the table, test 
16: A4B4C1 is $85 \mathrm{~mm}$ EPS polystyrene foam board (A4), $200 \mathrm{~mm}$ EPS polystyrene foam board (B4), plastic steel frame, and triple glass window $6+V+6$ Low-e $+12 A+6$ (C1) for comparison experiment. The purpose is to verify whether the optimal solution is optimal.

Use Design Builder software to simulate the two sets of experiments. It can be concluded that the annual energy consumption of A4B4C1 is 309.44 MWh and the annual carbon emission is $115,620 \mathrm{~kg}$, the energy-saving rate is $32.24 \%$, and the carbon dioxide emission reduction rate is $29.59 \%$. The annual energy consumption and annual carbon emissions of A4B4C4 are $305.84 \mathrm{MWh}$ and $114,430 \mathrm{~kg}$, respectively, the energy-saving rate is $33.03 \%$, and the carbon dioxide emission reduction rate is $30.32 \%$. It is confirmed that plan A4B4C4 is the optimal parameter modification plan for the residential building.

\subsection{Economic Analysis}

The NPV of the 16 groups of orthogonal test schemes and the NPV of the original design scheme, for a total of 17 groups of schemes, were determined using the calculation model (2)-(5), where the market price of standard coal is $0.01 \mathrm{USD} / \mathrm{kg}$ in Jilin province. The calorific value of standard coal is $29,307.6 \mathrm{~kJ} / \mathrm{kg}$, and the combustion rate of heating coal is taken as 0.7 . On 16 July 2021, the national carbon emission trading market went online for trading. The volume of carbon emission allowance (CEA) listed agreement trading in the national carbon market was 4,103,953 tons, with a turnover of USD 330,321,798.32 and a closing price of $8.05 \mathrm{USD} /$ ton, so the carbon trading price was based on The China carbon trading market price was $8.00 \mathrm{USD} /$ ton. The community was built in 2009 , and the expected service life is 50 years. The results are shown in Figure 8.

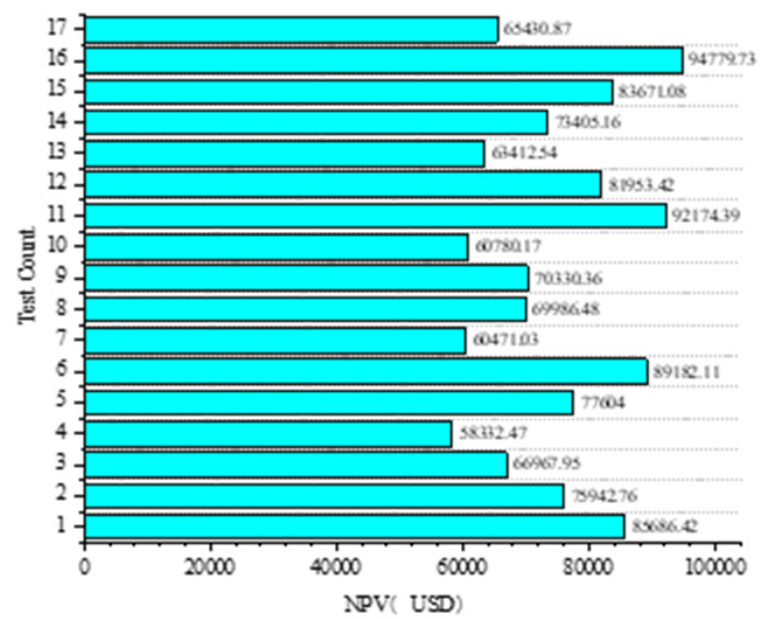

Figure 8. Net present value table.

Figure 9 shows that the static and discounted payback periods for all 17 experimental groups are less than 50 years, and therefore all 17 experimental groups are feasible. Therefore, the best solution for selecting the building design parameters from the economic point of view is Test 16, A4B4C1, $85 \mathrm{~mm}$ EPS polystyrene foam board (A4), $200 \mathrm{~mm}$ EPS polystyrene foam board (B4), plastic steel frame, and triple glass window $6+\mathrm{V}+6$ Low-e $+12 \mathrm{~A}+6(\mathrm{C} 1)$. The annual energy consumption is $309.44 \mathrm{MWh}$, annual carbon emission is $115,620 \mathrm{~kg}$, the energy-saving rate is $32.24 \%$, carbon dioxide emission reduction rate is $29.59 \%$. The Static payback period is 2.51 years. The discounted payback period is 2.72 years, and the net present value is USD 94,754.42. 


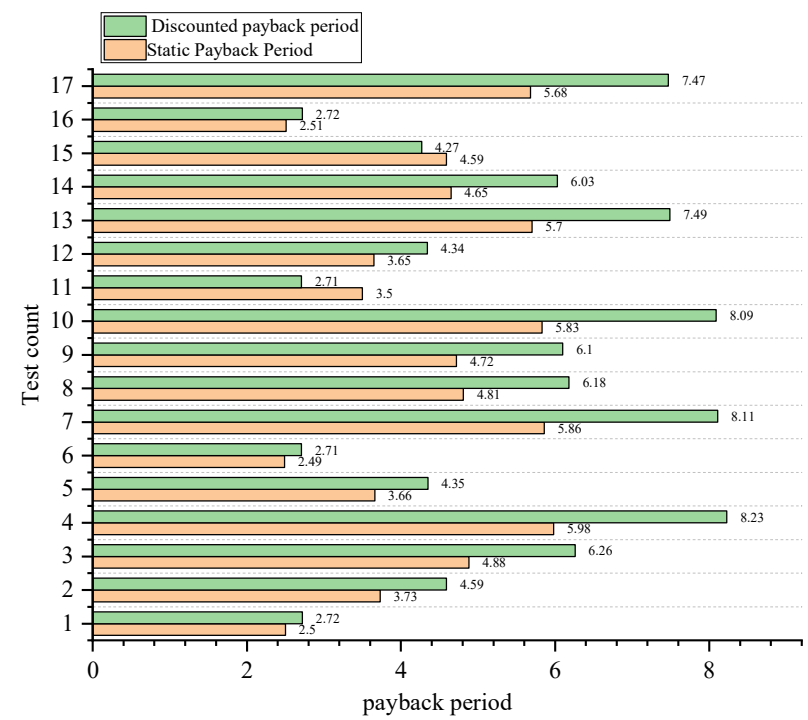

Figure 9. Payback period table.

\section{Sensitivity Analysis}

The sensitivity analysis aims at the robustness of the findings and discusses the influence of other elements on the results [34]. Because this chapter focuses on economic analysis, a sensitivity analysis of the uncertainty factors affecting the NPV was performed. The three variables considered in the calculation of NPV in this paper are annual cost savings $(C I)$, the initial investment cost $(C O)$, and the discount rate. Because the initial investment cost only exists for the first year, this study performs a two-factor sensitivity analysis on the two major sensitivity factors, cost savings and discount rate, to evaluate the potential changes in various uncertainty elements in the project reality.

Assuming that the percentage change in incremental cost is $x$ and the value of change in the discount rate is $r$, according to Equation (7), the net present value is

$$
N P V=-C I(1-x)+C O \frac{(1+r)^{50}-1}{r(1+r)^{50}}
$$

The values of $C I$ and $C O$ were taken as obtained in the above calculation.

When NPV is equal to 0,17 equations are obtained with $r$ values of $1 \%, 2 \%, 3 \%, 4 \%$, $5 \% \ldots . .19 \%, 20 \%$, the corresponding $x$-value statistics are shown in Table 7 , and the function curves are plotted as shown in Figure 10.

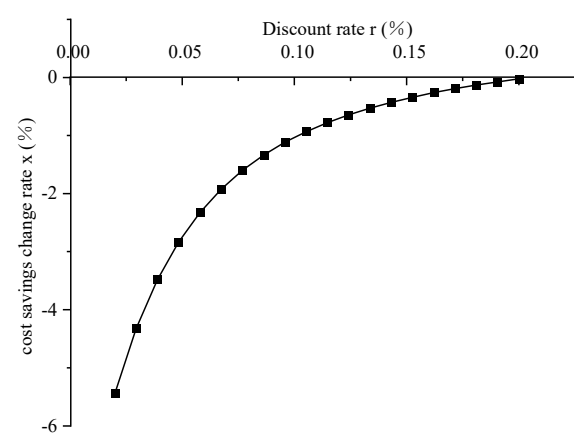

(a) Function (1)

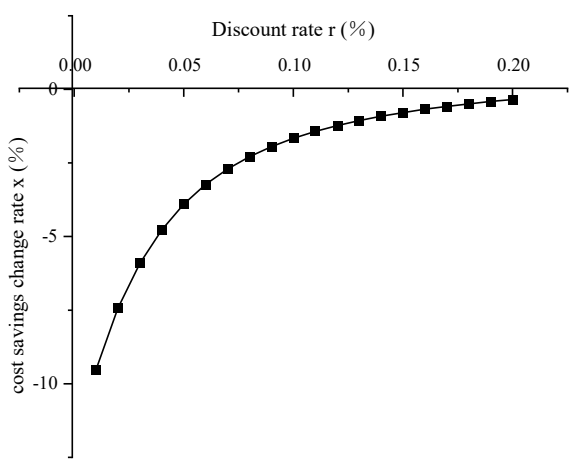

(b) Function (2)

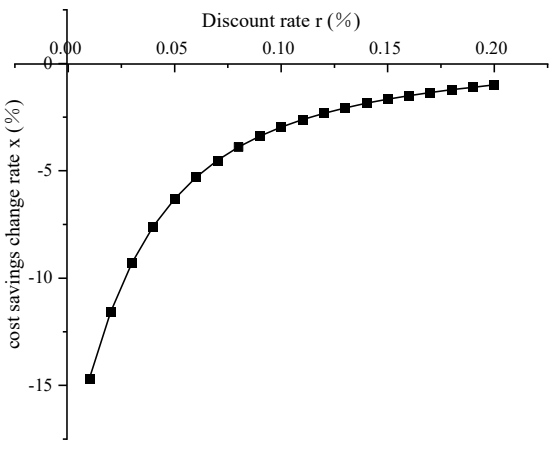

(c) Function (3)

Figure 10. Cont. 


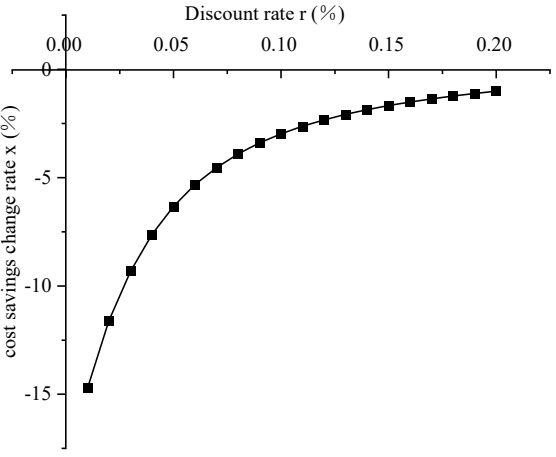

(d) Function (4)

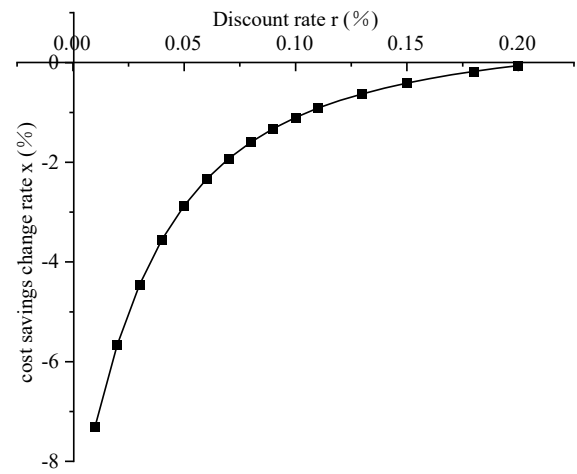

(g) Function (7)

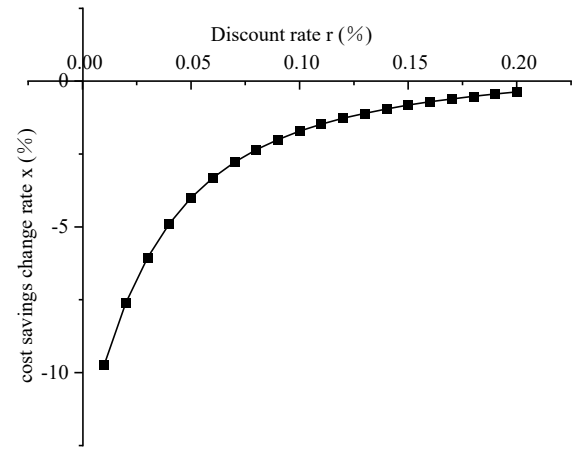

(j) Function (10)

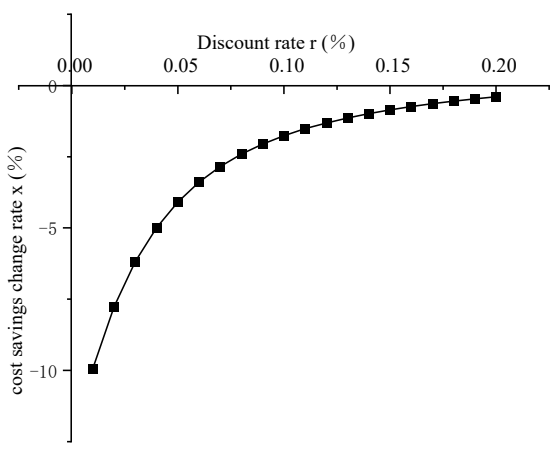

(m) Function (13)

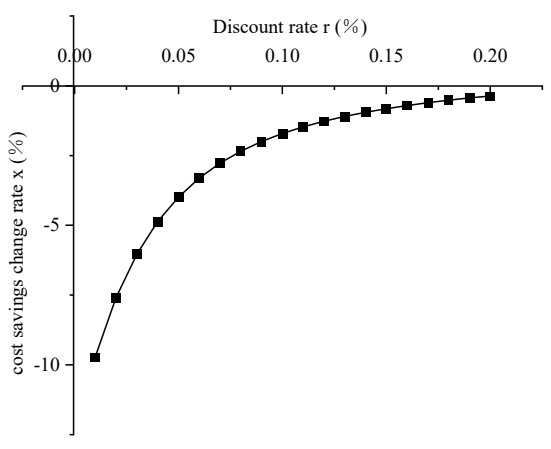

(e) Function (5)

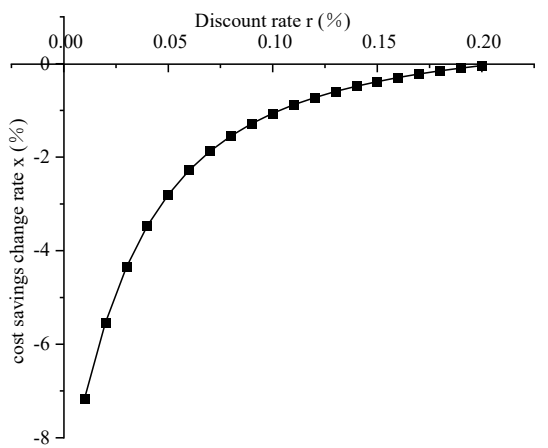

(h) Function (8)

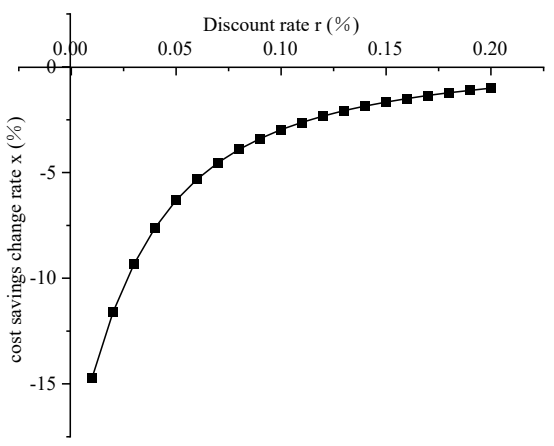

(k) Function (11)

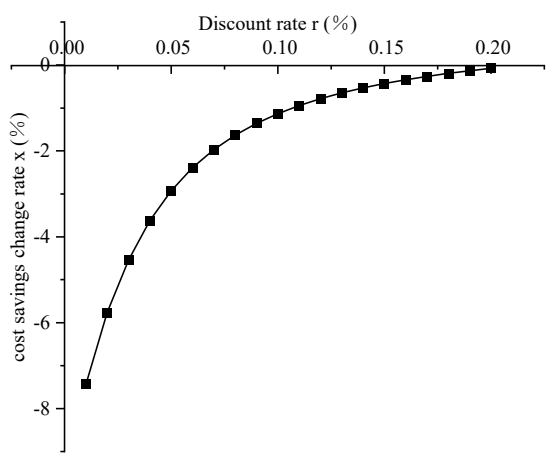

(n) Function (14)

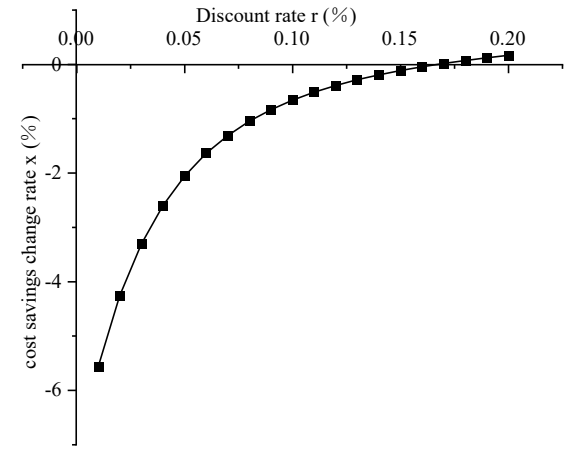

(f) Function (6)

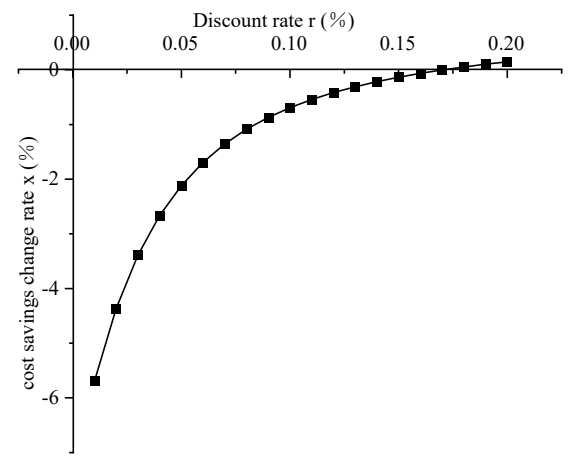

(i) Function (9)

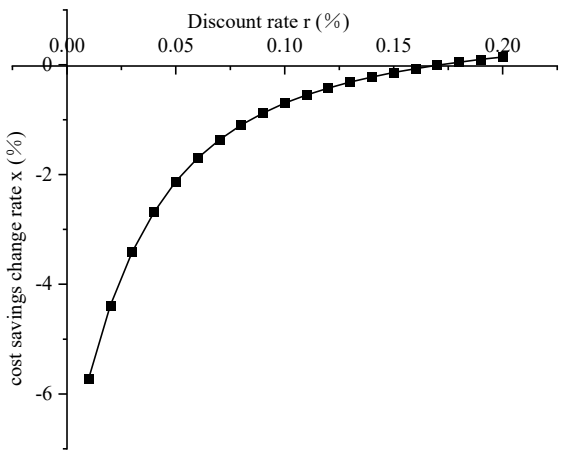

(l) Function (12)

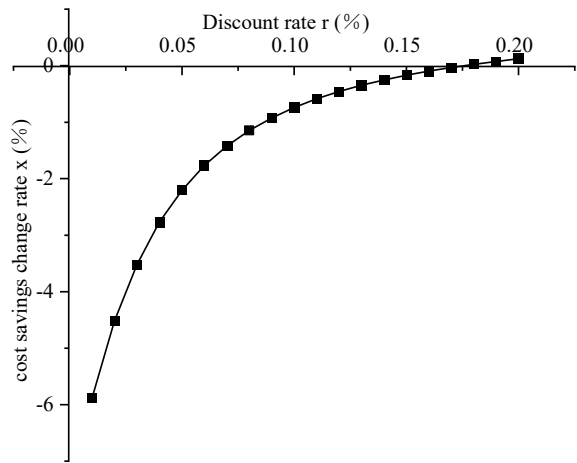

(o) Function (15)

Figure 10. Cont. 


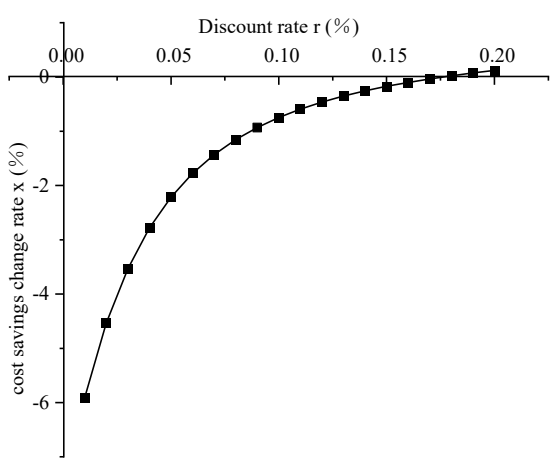

(p) Function (16)

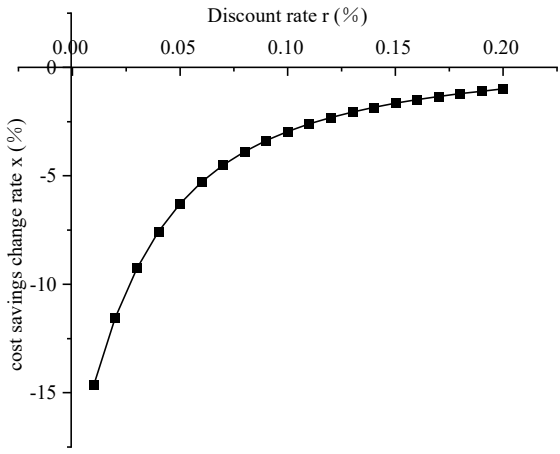

(q) Function (17)

Figure 10. Two-factor sensitivity incremental cost and discount rate analysis graph.

Table 7. Table of limiting values of the corresponding cost savings change rates at different discount rates.

\begin{tabular}{|c|c|c|c|c|c|c|c|c|c|c|}
\hline \multicolumn{11}{|c|}{ Function $(1) x=1-0.3998 \times\left[(1+r)^{\wedge} 50-1\right] /\left[r \times(1+r)^{\wedge} 50\right]$} \\
\hline$r$ & $1 \%$ & $2 \%$ & $3 \%$ & $4 \%$ & $5 \%$ & $6 \%$ & $7 \%$ & $8 \%$ & $9 \%$ & $10 \%$ \\
\hline$x$ & -14.67 & -11.56 & -9.29 & -7.59 & -6.30 & -5.30 & -4.52 & -3.89 & -3.38 & -2.96 \\
\hline$r$ & $11 \%$ & $12 \%$ & $13 \%$ & $14 \%$ & $15 \%$ & $16 \%$ & $17 \%$ & $18 \%$ & $19 \%$ & $20 \%$ \\
\hline$x$ & -2.61 & -2.32 & -2.07 & -1.85 & -1.66 & -1.50 & -1.35 & -1.22 & -1.10 & -1.00 \\
\hline \multicolumn{11}{|c|}{ Function $(2) x=1-0.2684 \times\left[(1+r)^{\wedge} 50-1\right] /\left[r \times(1+r)^{\wedge} 50\right]$} \\
\hline$r$ & $1 \%$ & $2 \%$ & $3 \%$ & $4 \%$ & $5 \%$ & $6 \%$ & $7 \%$ & $8 \%$ & $9 \%$ & $10 \%$ \\
\hline$x$ & -9.52 & -7.43 & -5.92 & -4.77 & -3.90 & -3.23 & -2.70 & -2.28 & -1.94 & -1.66 \\
\hline$r$ & $11 \%$ & $12 \%$ & $13 \%$ & $14 \%$ & $15 \%$ & $16 \%$ & $17 \%$ & $18 \%$ & $19 \%$ & $20 \%$ \\
\hline$x$ & -1.43 & -1.23 & -1.06 & -0.91 & -0.79 & -0.68 & -0.58 & -0.49 & -0.41 & -0.34 \\
\hline \multicolumn{11}{|c|}{ Function (3) $x=1-0.2048 \times\left[(1+r)^{\wedge} 50-1\right] /\left[r \times(1+r)^{\wedge} 50\right]$} \\
\hline$r$ & $1 \%$ & $2 \%$ & $3 \%$ & $4 \%$ & $5 \%$ & $6 \%$ & $7 \%$ & $8 \%$ & $9 \%$ & $10 \%$ \\
\hline$x$ & -7.03 & -5.44 & -4.27 & -3.40 & -2.74 & -2.23 & -1.83 & -1.51 & -1.24 & -1.03 \\
\hline$r$ & $11 \%$ & $12 \%$ & $13 \%$ & $14 \%$ & $15 \%$ & $16 \%$ & $17 \%$ & $18 \%$ & $19 \%$ & $20 \%$ \\
\hline$x$ & -0.85 & -0.70 & -0.57 & -0.46 & -0.36 & -0.28 & -0.20 & -0.14 & -0.08 & -0.02 \\
\hline \multicolumn{11}{|c|}{ Function $(4) x=1-0.1673 \times\left[(1+r)^{\wedge} 50-1\right] /\left[r \times(1+r)^{\wedge} 50\right]$} \\
\hline$r$ & $1 \%$ & $2 \%$ & $3 \%$ & $4 \%$ & $5 \%$ & $6 \%$ & $7 \%$ & $8 \%$ & $9 \%$ & $10 \%$ \\
\hline$x$ & -5.56 & -4.26 & -3.30 & -2.59 & -2.05 & -1.64 & -1.31 & -1.05 & -0.83 & -0.66 \\
\hline$r$ & $11 \%$ & $12 \%$ & $13 \%$ & $14 \%$ & $15 \%$ & $16 \%$ & $17 \%$ & $18 \%$ & $19 \%$ & $20 \%$ \\
\hline$x$ & -0.51 & -0.39 & -0.28 & -0.19 & -0.11 & -0.04 & 0.02 & 0.07 & 0.12 & 0.16 \\
\hline \multicolumn{11}{|c|}{ Function (5) $x=1-0.2734 \times\left[(1+r)^{\wedge} 50-1\right] /\left[r \times(1+r)^{\wedge} 50\right]$} \\
\hline$r$ & $1 \%$ & $2 \%$ & $3 \%$ & $4 \%$ & $5 \%$ & $6 \%$ & $7 \%$ & $8 \%$ & $9 \%$ & $10 \%$ \\
\hline$x$ & -9.72 & -7.59 & -6.03 & -4.87 & -3.99 & -3.31 & -2.77 & -2.34 & -2.00 & -1.71 \\
\hline$r$ & $11 \%$ & $12 \%$ & $13 \%$ & $14 \%$ & $15 \%$ & $16 \%$ & $17 \%$ & $18 \%$ & $19 \%$ & $20 \%$ \\
\hline$x$ & -1.47 & -1.27 & -1.10 & -0.95 & -0.82 & -0.71 & -0.61 & -0.52 & -0.44 & -0.37 \\
\hline
\end{tabular}


Table 7. Cont.

\begin{tabular}{|c|c|c|c|c|c|c|c|c|c|c|}
\hline \multicolumn{11}{|c|}{ Function $(6) x=1-0.4011 \times\left[(1+r)^{\wedge} 50-1\right] /\left[r \times(1+r)^{\wedge} 50\right]$} \\
\hline$r$ & $1 \%$ & $2 \%$ & $3 \%$ & $4 \%$ & $5 \%$ & $6 \%$ & $7 \%$ & $8 \%$ & $9 \%$ & $10 \%$ \\
\hline$x$ & -14.72 & -11.60 & -9.32 & -7.62 & -6.33 & -5.32 & -4.54 & -3.91 & -3.40 & -2.98 \\
\hline$r$ & $11 \%$ & $12 \%$ & $13 \%$ & $14 \%$ & $15 \%$ & $16 \%$ & $17 \%$ & $18 \%$ & $19 \%$ & $20 \%$ \\
\hline$x$ & -2.63 & -2.33 & -2.08 & -1.86 & -1.67 & -1.51 & -1.36 & -1.23 & -1.11 & -1.01 \\
\hline \multicolumn{11}{|c|}{ Function $(7) x=1-0.1707 \times\left[(1+r)^{\wedge} 50-1\right] /\left[r \times(1+r)^{\wedge} 50\right]$} \\
\hline$r$ & $1 \%$ & $2 \%$ & $3 \%$ & $4 \%$ & $5 \%$ & $6 \%$ & $7 \%$ & $8 \%$ & $9 \%$ & $10 \%$ \\
\hline$x$ & -5.69 & -4.36 & -3.39 & -2.67 & -2.12 & -1.69 & -1.36 & -1.09 & -0.87 & -0.69 \\
\hline$r$ & $11 \%$ & $12 \%$ & $13 \%$ & $14 \%$ & $15 \%$ & $16 \%$ & $17 \%$ & $18 \%$ & $19 \%$ & $20 \%$ \\
\hline$x$ & -0.54 & -0.42 & -0.31 & -0.22 & -0.14 & -0.07 & 0.00 & 0.05 & 0.10 & 0.15 \\
\hline \multicolumn{11}{|c|}{ Function $(8) x=1-0.2081 \times\left[(1+r)^{\wedge} 50-1\right] /\left[r \times(1+r)^{\wedge} 50\right]$} \\
\hline$r$ & $1 \%$ & $2 \%$ & $3 \%$ & $4 \%$ & $5 \%$ & $6 \%$ & $7 \%$ & $8 \%$ & $9 \%$ & $10 \%$ \\
\hline$x$ & -7.16 & -5.54 & -4.35 & -3.47 & -2.80 & -2.28 & -1.87 & -1.55 & -1.28 & -1.06 \\
\hline$r$ & $11 \%$ & $12 \%$ & $13 \%$ & $14 \%$ & $15 \%$ & $16 \%$ & $17 \%$ & $18 \%$ & $19 \%$ & $20 \%$ \\
\hline$x$ & -0.88 & -0.73 & -0.60 & -0.48 & -0.39 & -0.30 & -0.22 & -0.16 & -0.10 & -0.04 \\
\hline \multicolumn{11}{|c|}{ Function (9) $x=1-0.2119 \times\left[(1+r)^{\wedge} 50-1\right] /\left[r \times(1+r)^{\wedge} 50\right]$} \\
\hline$r$ & $1 \%$ & $2 \%$ & $3 \%$ & $4 \%$ & $5 \%$ & $6 \%$ & $7 \%$ & $8 \%$ & $9 \%$ & $10 \%$ \\
\hline$x$ & -7.31 & -5.66 & -4.45 & -3.55 & -2.87 & -2.34 & -1.92 & -1.59 & -1.32 & -1.10 \\
\hline$r$ & $11 \%$ & $12 \%$ & $13 \%$ & $14 \%$ & $15 \%$ & $16 \%$ & $17 \%$ & $18 \%$ & $19 \%$ & $20 \%$ \\
\hline$x$ & -0.92 & -0.76 & -0.63 & -0.51 & 0.41 & 0.32 & -0.25 & -0.18 & -0.12 & -0.06 \\
\hline \multicolumn{11}{|c|}{ Function $(10) x=1-0.1714 \times\left[(1+r)^{\wedge} 50-1\right] /\left[r \times(1+r)^{\wedge} 50\right]$} \\
\hline$r$ & $1 \%$ & $2 \%$ & $3 \%$ & $4 \%$ & $5 \%$ & $6 \%$ & $7 \%$ & $8 \%$ & $9 \%$ & $10 \%$ \\
\hline$x$ & -5.72 & -4.39 & -3.41 & -2.68 & -2.13 & -1.70 & -1.37 & -1.10 & -0.88 & -0.70 \\
\hline$r$ & $11 \%$ & $12 \%$ & $13 \%$ & $14 \%$ & $15 \%$ & $16 \%$ & $17 \%$ & $18 \%$ & $19 \%$ & $20 \%$ \\
\hline$x$ & -0.55 & -0.42 & -0.32 & -0.22 & -0.14 & -0.07 & -0.01 & 0.05 & 0.10 & 0.14 \\
\hline \multicolumn{11}{|c|}{ Function $(11) x=1-0.4006 \times\left[(1+r)^{\wedge} 50-1\right] /\left[r \times(1+r)^{\wedge} 50\right]$} \\
\hline$r$ & $1 \%$ & $2 \%$ & $3 \%$ & $4 \%$ & $5 \%$ & $6 \%$ & $7 \%$ & $8 \%$ & $9 \%$ & $10 \%$ \\
\hline$x$ & -14.70 & -11.59 & -9.31 & $-7,61$ & -6.31 & -5.31 & -4.53 & -3.90 & -3.39 & 2.97 \\
\hline$r$ & $11 \%$ & $12 \%$ & $13 \%$ & $14 \%$ & $15 \%$ & $16 \%$ & $17 \%$ & $18 \%$ & $19 \%$ & $20 \%$ \\
\hline$x$ & -2.62 & -2.33 & -2.07 & -1.86 & -1.67 & -1.50 & -1.36 & -1.22 & -1.11 & -1.00 \\
\hline \multicolumn{11}{|c|}{ Function $(12) x=1-0.2739 \times\left[(1+r)^{\wedge} 50-1\right] /\left[r \times(1+r)^{\wedge} 50\right]$} \\
\hline$r$ & $1 \%$ & $2 \%$ & $3 \%$ & $4 \%$ & $5 \%$ & $6 \%$ & $7 \%$ & $8 \%$ & $9 \%$ & $10 \%$ \\
\hline$x$ & -9.74 & 7.61 & -6.05 & -4.88 & -4.00 & -3.32 & -2.78 & -2.35 & -2.00 & -1.72 \\
\hline$r$ & $11 \%$ & $12 \%$ & $13 \%$ & $14 \%$ & $15 \%$ & $16 \%$ & $17 \%$ & $18 \%$ & $19 \%$ & $20 \%$ \\
\hline$x$ & -1.48 & -1.27 & -1.10 & -0.95 & -0.82 & -0.71 & -0.61 & -0.52 & -0.44 & -0.37 \\
\hline \multicolumn{11}{|c|}{ Function (13) $x=1-0.1755 \times\left[(1+r)^{\wedge} 50-1\right] /\left[r \times(1+r)^{\wedge} 50\right]$} \\
\hline$r$ & $1 \%$ & $2 \%$ & $3 \%$ & $4 \%$ & $5 \%$ & $6 \%$ & $7 \%$ & $8 \%$ & $9 \%$ & $10 \%$ \\
\hline$x$ & -5.88 & -4.51 & -3.52 & -2.77 & -2.20 & -1.77 & -1.42 & -1.15 & -0.92 & -0.74 \\
\hline$r$ & $11 \%$ & $12 \%$ & $13 \%$ & $14 \%$ & $15 \%$ & $16 \%$ & $17 \%$ & $18 \%$ & $19 \%$ & $20 \%$ \\
\hline$x$ & -0.59 & -0.46 & -0.35 & -0.25 & -0.17 & -0.10 & -0.03 & -0.02 & 0.08 & 0.12 \\
\hline
\end{tabular}


Table 7. Cont.

\begin{tabular}{|c|c|c|c|c|c|c|c|c|c|c|}
\hline \multicolumn{11}{|c|}{ Function $(14) x=1-0.2151 \times\left[(1+r)^{\wedge} 50-1\right] /\left[r \times(1+r)^{\wedge} 50\right]$} \\
\hline$r$ & $1 \%$ & $2 \%$ & $3 \%$ & $4 \%$ & $5 \%$ & $6 \%$ & $7 \%$ & $8 \%$ & $9 \%$ & $10 \%$ \\
\hline$x$ & -7.43 & -5.76 & -4.53 & -3.62 & -2.93 & -2.39 & -1.97 & -1.63 & -1.36 & -1.13 \\
\hline$r$ & $11 \%$ & $12 \%$ & $13 \%$ & $14 \%$ & $15 \%$ & $16 \%$ & $17 \%$ & $18 \%$ & $19 \%$ & $20 \%$ \\
\hline$x$ & -0.94 & -0.79 & -0.65 & -0.53 & -0.43 & -0.34 & -0.26 & -0.19 & -0.13 & -0.08 \\
\hline \multicolumn{11}{|c|}{ Function $(15) x=1-0.2788 \times\left[(1+r)^{\wedge} 50-1\right] /\left[r \times(1+r)^{\wedge} 50\right]$} \\
\hline$r$ & $1 \%$ & $2 \%$ & $3 \%$ & $4 \%$ & $5 \%$ & $6 \%$ & $7 \%$ & $8 \%$ & $9 \%$ & $10 \%$ \\
\hline$x$ & -9.93 & -7.76 & -6.17 & -4.99 & -4.09 & -3.39 & -2.85 & -2.41 & -2.06 & -1.76 \\
\hline$r$ & $11 \%$ & $12 \%$ & $13 \%$ & $14 \%$ & $15 \%$ & $16 \%$ & $17 \%$ & $18 \%$ & $19 \%$ & $20 \%$ \\
\hline$x$ & -1.52 & -1.31 & -1.14 & -0.99 & -0.86 & -0.74 & -0.64 & -0.55 & -0.47 & -0.39 \\
\hline \multicolumn{11}{|c|}{ Function $(16) x=1-0.3988 \times\left[(1+r)^{\wedge} 50-1\right] /\left[r \times(1+r)^{\wedge} 50\right]$} \\
\hline$r$ & $1 \%$ & $2 \%$ & $3 \%$ & $4 \%$ & $5 \%$ & $6 \%$ & $7 \%$ & $8 \%$ & $9 \%$ & $10 \%$ \\
\hline$x$ & -14.63 & -11.53 & -9.26 & -7.57 & -6.28 & -5.29 & -4.50 & -3.88 & -3.37 & -2.95 \\
\hline$r$ & $11 \%$ & $12 \%$ & $13 \%$ & $14 \%$ & $15 \%$ & $16 \%$ & $17 \%$ & $18 \%$ & $19 \%$ & $20 \%$ \\
\hline$x$ & -2.61 & -2.31 & -2.06 & -1.84 & -1.66 & -1.49 & -1.34 & -1.21 & -1.10 & -0.99 \\
\hline \multicolumn{11}{|c|}{ Function $(17) x=1-0.1761 \times\left[(1+r)^{\wedge} 50-1\right] /\left[r \times(1+r)^{\wedge} 50\right]$} \\
\hline$r$ & $1 \%$ & $2 \%$ & $3 \%$ & $4 \%$ & $5 \%$ & $6 \%$ & $7 \%$ & $8 \%$ & $9 \%$ & $10 \%$ \\
\hline$x$ & -5.90 & -4.53 & -3.53 & -2.78 & -2.21 & -1.78 & -1.43 & -1.15 & -0.93 & -0.75 \\
\hline$r$ & $11 \%$ & $12 \%$ & $13 \%$ & $14 \%$ & $15 \%$ & $16 \%$ & $17 \%$ & $18 \%$ & $19 \%$ & $20 \%$ \\
\hline$x$ & -0.59 & -0.46 & -0.35 & -0.26 & -0.17 & -0.10 & -0.04 & 0.02 & 0.07 & 0.12 \\
\hline
\end{tabular}

Each point on the 17 curves corresponding to $(r, x)$ makes the NPV equal to 0 as the critical line. If the NPV at any point in the upper left region of the curve is greater than 0 , the project is economically feasible; if the NPV at any point in the lower right region is less than 0 , the project is economically infeasible.

As can be seen from the data in Table 7, when the discount rate changes, it is guaranteed that the project remains economically feasible as long as the rate of change of the actual cost savings is greater than the $\mathrm{x}$-limit value corresponding to the value of $r$ in the table.

\section{Conclusions}

In this paper, a residential building in Changchun, Jilin Province, was used as an example to build a simulation model by Design Builder software to simulate the energy consumption and carbon dioxide emission of 33 groups of design solutions, including building facades, windows, and roofs. The residential building was used as a modification parameter. The results of this paper are as follows.

(1) The results show that the best parameter design plan for the project from the perspective of $\mathrm{CO}_{2}$ reduction is selected as $85 \mathrm{~mm}$ thickness of EPS polystyrene foam panels for the exterior walls, $200 \mathrm{~mm}$ thickness of EPS polystyrene foam panels for the roof, $6+\mathrm{V}+6$ Low-e $+12 \mathrm{~A}+6$, and semi-tempered vacuum glass plastic windows. The implementation of the plan will result in a $30.32 \%$ reduction in $\mathrm{CO}_{2}$ emissions and a $33.03 \%$ reduction in energy efficiency;

(2) The best parameter design plan for this project from the economic point of view was selected as $85 \mathrm{~mm}$ EPS polystyrene foam board, $200 \mathrm{~mm}$ EPS polystyrene foam board, $6+\mathrm{V}+6$ Low-e $+12 \mathrm{~A}+6$, and normal insulated glass plastic steel windows.

The focus of this paper is to reduce carbon dioxide emissions in Jilin Province, so the best parameter design scheme finally selected in this paper is $85 \mathrm{~mm}$ EPS polystyrene foam panel thickness for exterior walls, $200 \mathrm{~mm}$ EPS polystyrene foam panel thickness for the 
roof, semi-tempered plastic steel frame, and triple glass window $6+\mathrm{V}+6$ Low-e $+12 \mathrm{~A}+6$. The discounted payback period and the net present value of the optimized design scheme were calculated, the static payback period was 5.68 years and the discounted payback period of the retrofit design scheme was 7.47, and the net present value was USD 65,413.39.

The parameters of the residential building model in the severe cold region have an impact on this study, and the results may vary based on the parameter settings. This paper only simulates residential buildings in Changchun, Jilin Province, and not in other residential buildings in other severe cold regions. Furthermore, while choosing model parameters only selects the variable focus as the envelope structure, if we want to optimize the design of the whole residence in the cold region, we can also look at the number of air changes, window-to-wall ratio building orientation, and other factors. The findings of this study, on the other hand, can be used to develop experimental methods for determining the selection of design options for parameters of residential buildings in severe cold regions for the purpose of reducing emissions, as well as a reference for decision-making during the early stages of residential building design. According to the results of the economic calculations, vacuum glazing has a significant impact on the net present value. Although the use of vacuum glazing obviously improves the abatement rate of residential buildings, it also increase the economic cost. At present, the cost of vacuum glass in China is generally high, and the research and development of vacuum glass and the control of vacuum glass cost should be increased to make vacuum glass better used in the building field.

Author Contributions: Conceptualization, H.Y.; methodology, H.Y.; software, H.Y.; formal analysis, H.Y.; data collection, H.Y.; review and editing, K.K. and M.H.; All authors have read and agreed to the published version of the manuscript.

Funding: This research received no external funding.

Informed Consent Statement: This research does not involve humans.

Data Availability Statement: Data are contained within this study.

Conflicts of Interest: The authors declare no conflict of interest.

\section{References}

1. Le Quéré, C.; Andrew, R.M.; Friedlingstein, P.; Sitch, S.; Hauck, J.; Pongratz, J.; Pickers, P.A.; Korsbakken, J.I.; Peters, G.P.; Canadell, J.G. Global carbon budget 2018. Earth Syst. Sci. Data 2018, 10, 2141-2194. [CrossRef]

2. China Building Energy Conservation Association. China Building Energy Consumption Research Report; China Construction Industry Press: Beijing, China, 2021.

3. In 2020, My Country's Unit GDP Reduction in Carbon Dioxide Emissions Exceeds the 13th Five-Year Plan Goal. Available online: https:/ /news.cctv.com/2020/10/21/ ARTIDkN02hTRiTyzLm8E65nE201021.shtml (accessed on 26 November 2021).

4. The Fourteenth Five-Year Plan for the National Economic and Social Development of the People's Republic of China and the Outline of the Long-Term Goals for 2035. China Water Resour. 2021, 3, 1-38.

5. Elbeltagi, E.; Wefki, H.; Abdrabou, S.; Dawood, M.; Ramzy, A. Visualized strategy for predicting buildings energy consumption during early design stage using parametric analysis. J. Build. Eng. 2017, 13, 127-136. [CrossRef]

6. Kardani, N.; Bardhan, A.; Kim, D.; Samui, P.; Zhou, A. Modelling the energy performance of residential buildings using advanced computational frameworks based on RVM, GMDH, ANFIS-BBO and ANFIS-IPSO. J. Build. Eng. 2021, 35, 102105. [CrossRef]

7. Hollberg, A.; Lichtenheld, T.; Klüber, N.; Ruth, J. Parametric real-time energy analysis in early design stages: A method for residential buildings in Germany. Energy Ecol. Environ. 2018, 3, 13-23. [CrossRef]

8. Carletti, C.; Sciurpi, F.; Pierangioli, L. The energy upgrading of existing buildings: Window and shading device typologies for energy efficiency refurbishment. Sustainability 2014, 6, 5354-5377. [CrossRef]

9. Alam, M.; Jamil, H.; Sanjayan, J.; Wilson, J. Energy saving potential of phase change materials in major Australian cities. Energy Build. 2014, 78, 192-201. [CrossRef]

10. Arabkoohsar, A.; Behzadi, A.; Alsagri, A.S. Techno-economic analysis and multi-objective optimization of a novel solar-based building energy system; An effort to reach the true meaning of zero-energy buildings. Energy Conver. Manag. 2021, 232, 113858. [CrossRef]

11. Huo, H.; Shao, J.; Huo, H. Contributions of energy-saving technologies to building energy saving in different climatic regions of China. Appl. Therm. Eng. 2017, 124, 1159-1168. [CrossRef]

12. Feehan, A.; Nagpal, H.; Marvuglia, A.; Gallagher, J. Adopting an integrated building energy simulation and life cycle assessment framework for the optimisation of facades and fenestration in building envelopes. J. Build. Eng. 2021, 43, 103138. [CrossRef] 
13. Bazzocchi, F.; Ciacci, C.; Di Naso, V. Evaluation of Environmental and Economic Sustainability for the Building Envelope of Low-Carbon Schools. Sustainability 2021, 13, 1702. [CrossRef]

14. Sampaio, P.R.; Salvazet, R.; Mandel, P.; Becker, G.; Chenu, D. Simulation and optimal control of heating and cooling systems: A case study of a commercial building. Energy Build. 2021, 246, 111102. [CrossRef]

15. Lin, C.-H.; Chen, M.-Y.; Tsay, Y.-S. Simulation Methodology Based on Wind and Thermal Performance for Early Building Optimization Design in Taiwan. Sustainability 2021, 13, 10033. [CrossRef]

16. Tavakolan, M.; Mostafazadeh, F.; Jalilzadeh Eirdmousa, S.; Safari, A.; Mirzaei, K. A parallel computing simulation-based multiobjective optimization framework for economic analysis of building energy retrofit: A case study in Iran. J. Build. Eng. 2022, 45, 103485. [CrossRef]

17. Inprom, N.; Jareemit, D. Efficient Envelope Designs to Maximize Residential Cooling Energy Savings in Bangkok Neighborhoods. Nakhara J. Environ. Des. Plann. 2021, 20, 103. [CrossRef]

18. Li, Q.; Wang, Y.; Ma, L.; Arıcı, M.; Li, D.; Yıldız, Ç.; Zhu, Y. Effect of sunspace and PCM louver combination on the energy saving of rural residences: Case study in a severe cold region of China. Sustain. Energy Technol. Assess. 2021, 45, 101126. [CrossRef]

19. Li, L.; Liu, X.; Zhang, T. Performance analysis and instant/delayed characteristics of a solar heating system used in cold regions. J. Build. Eng. 2021, 34, 101767. [CrossRef]

20. Ni, P.; Wang, W.; Ji, W.; Zhang, Y.; Yang, C. Research on theoretical energy saving rate of cooling and heating with intelligent temperature control of office buildings in Xinjiang typical climate zone. IOP Conf. Ser. Earth Environ. Sci. 2021, 675, 012026. [CrossRef]

21. Liu, C.; Mohammadpourkarbasi, H.; Sharples, S. Evaluating the potential energy savings of retrofitting low-rise suburban dwellings towards the Passivhaus EnerPHit standard in a hot summer/cold winter region of China. Energy Build. 2021, 231, 110555. [CrossRef]

22. Li, R.; Chen, S. Contrast analysis of energy consumption simulation software and summary of Design Builder application. Eng. Technol. 2017, 7, 296-297.

23. Teng, J.Y.; Liu, Y.D. Study on energy-saving contribution of passive retrofit measures of public building in a severely cold area. New Build. Mater. 2017, 3, 90-93.

24. Shen, J.; Shi, W.; Wang, Z. Research on the Selection of PPP Project Return Mechanism. Price Theory Pract. 2018, 9, 131-134.

25. Liu, Z. Incremental cost and development prospects of prefabricated buildings compared with traditional building models. Hous. Real Estate. 2018, 3, 236.

26. Xu, C.; Li, S. Analysis on optimum insulation thickness of external thermal insulation walls in Nanjing zone. J. South. Univ. 2019, $49,558-564$.

27. He, L.; Ren, L. Research on the introduction test technology of Ulmus golden leaf. Inn. Mong. For. Invest. Design. 2016, 39, 37-38.

28. JGJ26-2018; Design Standard for Energy Efficiency of Residential Buildings in Severe Cold and Cold Areas. Ministry of Housing and Urban-Rural Development of the People's Republic of China: Beijing, China, 2018.

29. Qi, X.; Sang, G.; Yang, L. Performance advantage analysis of external wall insulation system. In Proceedings of the 2007 National Conference on Building Environment and Building Energy Efficiency, Chengdu, China, 11-15 October 2007; pp. 142-146.

30. Luo, Y.; Liu, Z. Building Energy-Saving Technology and Application; Chemical Industry Press: Beijing, China, 2007.

31. DB22-T450-2007; Residential Building Energy Efficiency Design Standard (Energy Saving 65\%). Housing and Urban-Rural Development Department of Jilin Province: Changchun, China, 2009.

32. Hu, E. Building Energy Efficiency Technology; Beijing Institute of Technology Press: Beijing, China, 2018.

33. GB/T18091-2015; Optical and Thermal Performance of Glass Curtain Wall. China National Standardization Management Committee: Beijing, China, 2015.

34. Borenstein, M.; Hedges, L.V.; Higgins, J.P.T.; Rothstein, H.R. Introduction to Meta-Analysis; John Wiley \& Sons: Hoboken, NJ, USA, 2021. 